Note

\title{
Isolation and screening for plant growth-promoting (PGP) actinobacteria from Araucaria angustifolia rhizosphere soil
}

\author{
Rafael Leandro Figueiredo de Vasconcellos ${ }^{1}$; Mylenne Calciolari Pinheiro da Silva²; Carlos \\ Marcelo Ribeiro²; Elke Jurandy Bran Nogueira Cardoso ${ }^{3 *}$ \\ ${ }^{1}$ USP/ESALQ - Programa de Pós-Graduação em Solos e Nutrição de Plantas, C.P. 09 - 13418-900 - Piracicaba, \\ $S P$ - Brasil. \\ ${ }^{2} U S P / E S A L Q$ - Programa de Pós-Graduação em Microbiologia Agrícola. \\ ${ }^{3}$ USP/ESALQ - Depto. de Ciência do Solo - Laboratório de Microbiologia do Solo, C.P. 09 - 13418-900 - \\ Piracicaba, SP - Brasil. \\ *Corresponding author < ejbncard@esalq.usp.br>
}

\begin{abstract}
Actinobacteria are capable of playing several different roles in soil ecosystems. These microorganisms affect other organisms by producing secondary metabolites and are responsible for the degradation of different complex and relatively recalcitrant organic compounds. In our survey of actinobacteria isolated from the rhizosphere of Araucaria angustifolia, five culture media (AI, WYE, YCED, MSSC and LNMS) were compared for their effectiveness in isolating these microorganisms. When summing up all the isolates randomly obtained, we got 103 isolates. After isolation, the phosphate-solubilizing ability and the "in vitro" production of indole-acetic acid and chitinases were evaluated. The AI medium was ineffective for actinobacteria isolation, when it was compared with the other four culture media. Indole-acetic acid and chitinase were produced by respectively $36 \%$ and $24 \%$ of the strains tested. However, only $2 \%$ of the 103 strains presented some phosphate-solubilizing ability. These results demonstrate the biotechnological potential of these microorganisms.

Key words: Brazil Pine, selective culture media, indole-acetic acid, chitinase, phosphate solubilization
\end{abstract}

\section{Isolamento e seleção de actinobactérias promotoras do crescimento de plantas de solo rizosférico de Arancaria angustifolia}

\begin{abstract}
RESUMO: Actinobactérias são capazes de desenvolver diferentes funções no ecossistema edáfico. Esses microrganismos, além de interagir com outros grupos de microrganismos e plantas, ao produzir metabólitos secundários, são responsáveis pela degradação de diferentes compostos orgânicos. Com intuito de facilitar os estudos envolvendo actinobactérias encontradas em sistemas florestais, cinco meios de cultura (AI, WYE, YCED, MSSC e LNMS) foram avaliados quanto à eficiência em isolar estes microrganismos. Além disso, foi analisada a capacidade dos diferentes isolados em solubilizar fosfato de cálcio, produzir ácido indol-acético e quitinases. Dos cinco meios de cultura testados, somente o AI foi ineficiente em isolar actinobactérias. A produção de ácido indol-acético e quitinases foi observada em $36 \%$ e $24 \%$ dos isolados analisados, respectivamente. Contudo, apenas $2 \%$ dos 103 isolados foram capazes de solubilizar fosfato de cálcio. Estes resultados comprovam o potencial biotecnológico desses microrganismos.

Palavras-chave: Pinheiro Brasileiro, meios de cultura seletivos, ácido indol-acético, quitinase, solubilização de fosfato
\end{abstract}

\section{Introduction}

Araucaria angustifolia is a tree found in the Brazilian Pine Forest that belongs to the Atlantic Forest Biome. This tree has socio-economic and environmental importance (Lima and Capobianco, 1997), and its seeds are consumed by the fauna and are also appreciated by human beings (Carvalho, 1994). Due to the intense deforestation, less than $2 \%$ of the original Araucaria forest in Brazil is still remaining (Guerra et al., 2002). Therefore, $A$. angustifolia is classified as a critically endangered species, and studies involving its preservation and management, including the study of associated soil microorganisms, are urgently required.

An important group of microorganisms, that is almost unexplored in Brazil, comprises the actinobacteria (Streptomycetes) (Araújo et al., 2000; Gomes et al., 2000; Sousa et al., 2008). These filamentous organisms have a high $G+C$, propagate themselves by spores and grow through the soil in the form of hyphae (Stackebrandt et al., 1997). The actinobacteria are widely distributed in nature, being commonly found in soil, especially in the rhizosphere (Merzaeva and Shirokikh, 2006; Sousa et al., 2008). By means of their secondary metabolites, these microorganisms can influence plant development pro-

Sci. Agric. (Piracicaba, Braz.), v.67, n.6, p.743-746, November/December 2010 
ducing plant hormones, increasing the availability of mineral nutrients and also excreting antibiotics or toxins that act in the biological control of pathogens in the rhizosphere (Crawford, 1978; Hamdali, 2008; Miyadoh, 1993). They are well known for their extensive production of compounds with phosphate-solubilizing ability and compounds with high biotechnological potential such as chitinases, and antibiotics (Gomes et al., 2000; Hamdali et al., 2008; Miyadoh, 1993).

The first objective of this study was to evaluate the effectiveness of selective culture media for the isolation of actinobacteria from the $A$. angustifolia rhizosphere. Moreover, the potential of the obtained isolates to promote plant growth and biocontrol was analyzed through the evaluation of indole-acetic acid and chitinase production. The phosphate-solubilizing ability was also tested.

\section{Material and Methods}

The rhizospheric soil adhered to roots was sampled in the native forest of $A$. angustifolia, in the state of São Paulo, Brazil, located in the Mantiqueira mountain range

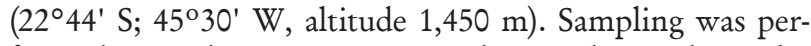
formed around nine trees. For each tree, three subsamples of roots with adhering rhizospheric soil were collected and homogenized, resulting nine composite samples.

The actinobacteria were isolated from rhizospheric soil by the serial dilution technique in Petri dishes, containing one of the culture media used by Crawford et al. (1993): AI (Actinomycetes Isolation Agar: $\mathrm{K}_{2} \mathrm{HPO}_{4}$, $0.5 \mathrm{~g} ; \mathrm{MgSO}_{4} .7 \mathrm{H}_{2} \mathrm{O}, 0.1 \mathrm{~g} ; \mathrm{FeSO}_{4} .7 \mathrm{H}_{2} \mathrm{O}, 1.0 \mathrm{mg}$; sodium caseinate, $2 \mathrm{~g}$; asparagine, $0.1 \mathrm{~g}$; sodium propionate $4 \mathrm{~g}$; glycerol, $5 \mathrm{~g}$; agar, 15 g; distilled water, $1000 \mathrm{~mL}$ ), YCED (Casamino Acids Yeast Extract Glucose Agar: yeast extract, $0.3 \mathrm{~g}$; casamino acids, $0.3 \mathrm{~g}$; D-glucose, $0.3 \mathrm{~g}$; agar, $20 \mathrm{~g}$; distilled water, $1000 \mathrm{~mL}$ ), WYE (Water Yeast Extract Agar: yeast extract, $0.25 \mathrm{~g} ; \mathrm{K}_{2} \mathrm{HPO}_{4}, 0.5 \mathrm{~g}$; agar, 20 g; distilled water, $1000 \mathrm{~mL}$ ), LNMS (Low-Nutrient Mineral Salts-Agar: yeast extract, $0.1 \mathrm{~g} ; \mathrm{K}_{2} \mathrm{HPO}_{4}, 2 \mathrm{~g} ; \mathrm{NaCl}$, $0.2 \mathrm{~g} ; \mathrm{MgSO}_{4} .7 \mathrm{H}_{2} \mathrm{O}, 0.005 \mathrm{~g} ; \mathrm{CaCO}_{3}, 0.05 \mathrm{~g} ; \mathrm{FeSO}_{4} .7 \mathrm{H}_{2} \mathrm{O}$, $0.01 \mathrm{~g}$; soluble starch, $0.1 \mathrm{~g}$; agar, $20 \mathrm{~g}$; distilled water, $1000 \mathrm{~mL}$ ) and MSSC (Mineral Salts Starch Casein Agar: $\mathrm{K}_{2} \mathrm{HPO}_{4}, 2 \mathrm{~g} ; \mathrm{NaCl}, 2 \mathrm{~g} ; \mathrm{MgSO}_{4} .7 \mathrm{H}_{2} \mathrm{O}, 0.05 \mathrm{~g} ; \mathrm{CaCO}_{3}$, $0.02 \mathrm{~g} ; \mathrm{FeSO}_{4} .7 \mathrm{H}_{2} \mathrm{O}, 0.01$; soluble starch, $10 \mathrm{~g} ; \mathrm{KNO}_{3}, 2 \mathrm{~g}$; casein, $0.3 \mathrm{~g}$; agar, $20 \mathrm{~g}$; distilled water, $1000 \mathrm{~mL}$ ).

The dilutions $\left(10^{-1}\right.$ to $\left.10^{-5}\right)$ were plated in duplicate, and the plates were incubated at $28^{\circ} \mathrm{C}$ for 10 days to allow for spore formation. After incubation, dry, powdery and small colonies with extremely slow growth were counted and selected randomly from mixed plate culture and transferred by streaking to a new plate with the same culture medium for purification. It is possible that actinobacterial colonies belonging to different families that do not show these characteristics, and could not be distinguished from other bacteria by macroscopic visualization were missed. The pure colonies were transferred to plates containing ISP2 culture medium (Pridham et al., 1957) (10 g glucose, $5 \mathrm{~g}$ malt extract and $5 \mathrm{~g}$ yeast extract with the $\mathrm{pH}$ adjusted to $7.2,15 \mathrm{~g}$ agar and $1000 \mathrm{~mL}$ distilled water), and incubated at $28^{\circ} \mathrm{C}$ for one week. Subsequently, each isolate was stored in $40 \%$ glycerol. The isolates were replicated every 3 months.

All strains isolated from $A$. angustifolia soil were tested for the production of indole-acetic acid with a colorimetric method described by Bric et al. (1991), with an adaptation that consisted in reading absorbance values in microplates. Each isolate was inoculated in test tubes containing $3 \mathrm{~mL}$ of Luria Bertani (LB) culture medium, supplemented with $1 \mathrm{~g} \mathrm{~L}^{-1}$ of the precursor of indole-acetic acid (L-tryptophan), and incubated at $28^{\circ} \mathrm{C}$ for 5 days under constant agitation. Afterwards, $1.5 \mathrm{~mL}$ of each homogenized culture was transferred to microtubes and centrifuged at $9500 \mathrm{~g}$ for two minutes and $100 \mu \mathrm{L}$ of the supernatant were transferred to microplate wells, following the addition of $100 \mu \mathrm{L}$ of the Salkowski reagent, consisting of $1 \mathrm{~mL}$ of $0.5 \mathrm{~mol} \mathrm{~L}^{-1}$ $\mathrm{FeCl}_{3}$ and $49 \mathrm{~mL}$ of $35 \% \mathrm{HClO}_{4}$.

Thirty minutes after the addition of the Salkowski reagent, the readings were carried out at $530 \mathrm{~nm}$, using a microplate reader Cary ${ }^{\circledR} 50$ (Varian. Walnut Creek. CA. USA). A reddish-pink color of the samples indicates the indole-acetic acid production.

To establish a standard curve a commercial solution of IAA was used.

The phosphate-solubilizing ability of the actinobacteria was evaluated by a modified method described by Katznelson and Bose (1959), using inorganic $\mathrm{P}\left(\mathrm{CaHPO}_{4}\right)$ as phosphate source. The culture medium was composed of $10 \mathrm{~g}$ glucose, $20 \mathrm{~g}$ agar, $2 \mathrm{~g}$ asparagine, $0.5 \mathrm{~g} \mathrm{MgSO}_{4}, 0.1 \mathrm{~g}$ $\mathrm{NaCl}, 0.1 \mathrm{~g} \mathrm{KCl}, 0.5 \mathrm{~g}$ yeast extract, $1000 \mathrm{~mL}$ distilled water and the $\mathrm{pH}$ was adjusted to 7.0 with $1 \mathrm{M} \mathrm{NaOH}$, before autoclaving. Fifty $\mathrm{mL}$ of sterile $10 \% \mathrm{~K}_{2} \mathrm{HPO}_{4}$ solution and $100 \mathrm{~mL}$ of sterile $10 \% \mathrm{CaCl}_{2}$ solution were added aseptically to the medium at $50^{\circ} \mathrm{C}$ and then the medium was dispensed into the petri plates. The reaction between $\mathrm{CaCl}_{2}$ and $\mathrm{K}_{2} \mathrm{HPO}_{4}$ produced $\mathrm{CaHPO}_{4}$ that turned the medium turbid and permitted the easy detection of dissolution haloes around the colonies. The strains were transferred, in duplicate, to petri dishes, each one being considered as an experimental unit. They were incubated at $28^{\circ} \mathrm{C}$ for 10 days, and the phosphate solubilizers showed a clear dissolution zone around the colonies.

The ability of the isolates to produce chitinases was assessed using a culture medium with chitin as unique carbon source as described by $\mathrm{Hsu}$ and Lockwood (1975): 4 g Chitin, $0.7 \mathrm{~g} \mathrm{~K}_{2} \mathrm{HPO}_{4}, 0.3 \mathrm{~g} \mathrm{KH}_{2} \mathrm{PO}_{4}, 0.5 \mathrm{~g}$ $\mathrm{MgSO}_{4} .5 \mathrm{H}_{2} \mathrm{O}, 0.01 \mathrm{~g} \mathrm{FeSO}_{4}, 7 \mathrm{H}_{2} 0.0 .001 \mathrm{~g} \mathrm{ZnSO}_{4}, 0.001 \mathrm{~g}$ $\mathrm{MnCl}_{2}, 20 \mathrm{~g}$ agar and $1000 \mathrm{~mL}$ distilled water.

After autoclaving, the $\mathrm{pH}$ was adjusted to 8.0, using sterilized $5 \mathrm{~N} \mathrm{NaOH}$. The isolates that formed a clear zone around the colony were considered as chitinase producers.

The statistical design was completely randomized with nine $A$. angustifolia trees as replicates and two plates per dilution for each tree. Data were log-transformed and were submitted to analysis of variance (ANOVA).Mean comparison was made using the Tukey test $(p<0.01)$ (SAS 2002). 


\section{Results and Discussion}

For isolation and quantification of the actinobacteria in rhizosphere soil of Araucaria forests, the most adequate dilution of a ten-fold dilution series was $10^{-3}$, resulting an average of ten colonies per plate. However, the number of contaminants was greater, when comparing with the $10^{-4}$ dilution. The UFC number of actinobacteria detected in this study is in line with Crawford et al. (1993) who reported a greater amount of actinobacteria in rhizosphere in comparison with surrounding soil. Media containing antibiotics were not used in our study because there are reports about their action also against the actinobacteria themselves (Goodfellow and Williams, 1983).

Among the four culture media evaluated, the AI medium does not seem to be favorable for most of these bacteria, since only very few colonies were formed. This culture medium is widely used (Anzai et al., 2008; Gomes et al., 2001) but, apparently, its effectiveness for isolation has not been previously compared with that of other media. The AI medium has sodium propionate in its composition that can inhibit bacteria and can also reduce the number of actinobacteria (Pereira et al., 1996). The other four culture media were equivalent and brought satisfactory results (Figure 1).

Of the 103 actinobacteria strains tested, 37 isolates $(36 \%)$ were able to produce indole-acetic acid. Six actinobacteria strains were outstanding (A4-8, L4-3, M46 , Y7-1, Y4-1, Y4-2), with a production above $40 \mu \mathrm{gL}^{-1}$ (Figure 2); it is more common to find values around 5 to $10 \mu \mathrm{g} \mathrm{mL} \mathrm{m}^{-1}$ referred to in the literature (Hynes et al., 2008), although much higher values also have been found. Microorganisms that produce auxins, as indole-acetic acid, are widely distributed in soil (Akbari et al., 2007; Hynes et al., 2008). Sousa et al. (2008) already stated that actinobacteria have a good potential as indole-acetic acid producers in Brazil. These auxins stimulate the growth and development of plants (Sousa et al., 2008). Therefore, they may be useful in the management of forest species, mainly in nurseries or during transplantation to the field.

Of the 103 isolates, $24 \%$ were able to produce chitinases. Chitinases may affect the growth of pathogenic fungi, degrading their cell wall, which is composed primarily of chitin. They have been used successfully in the control of plant diseases (Crawford et al., 1993; El-Tarabily et al., 2000; Toledo and Cardoso, 1975). However, only three strains (A4-1, Y2-3 and Y7-3) or 2\% of all isolates showed phosphate-solubilizing ability in vitro.

The microorganisms that interact with $A$. angustifolia have been relegated for many years. Only lately some findings in this area have been reported, especially by our group. This is the first time that the actinobacteria of the $A$. angustifolia rhizosphere attracted the attention of microbiologists interested in finding PGP bacteria. Our study was helpful to show the importance of this pine tree for researchers that work with actinobacteria

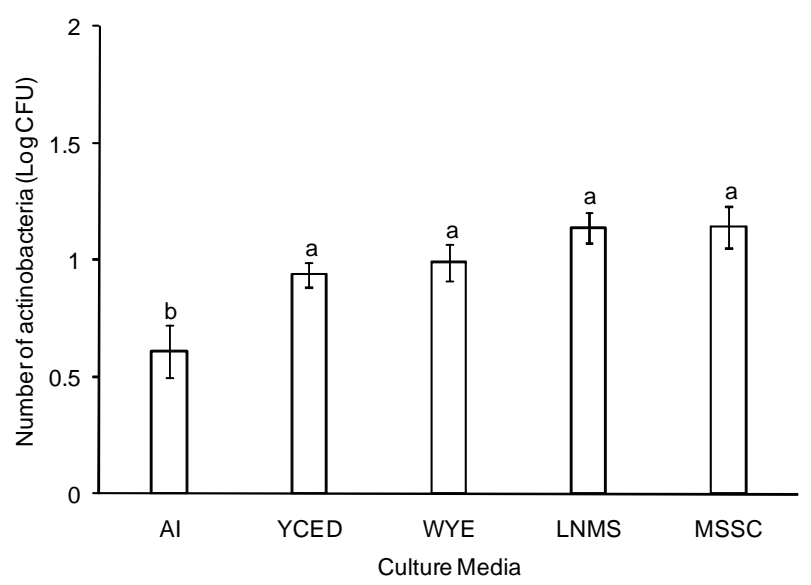

Figure 1 - Mean number of actinobacteria in each of the five culture media used in the study, and the standard error of the mean $(n=9)$. Bars followed by the same letter do not differ (Tukey test, $p \leq 0.01$ ).

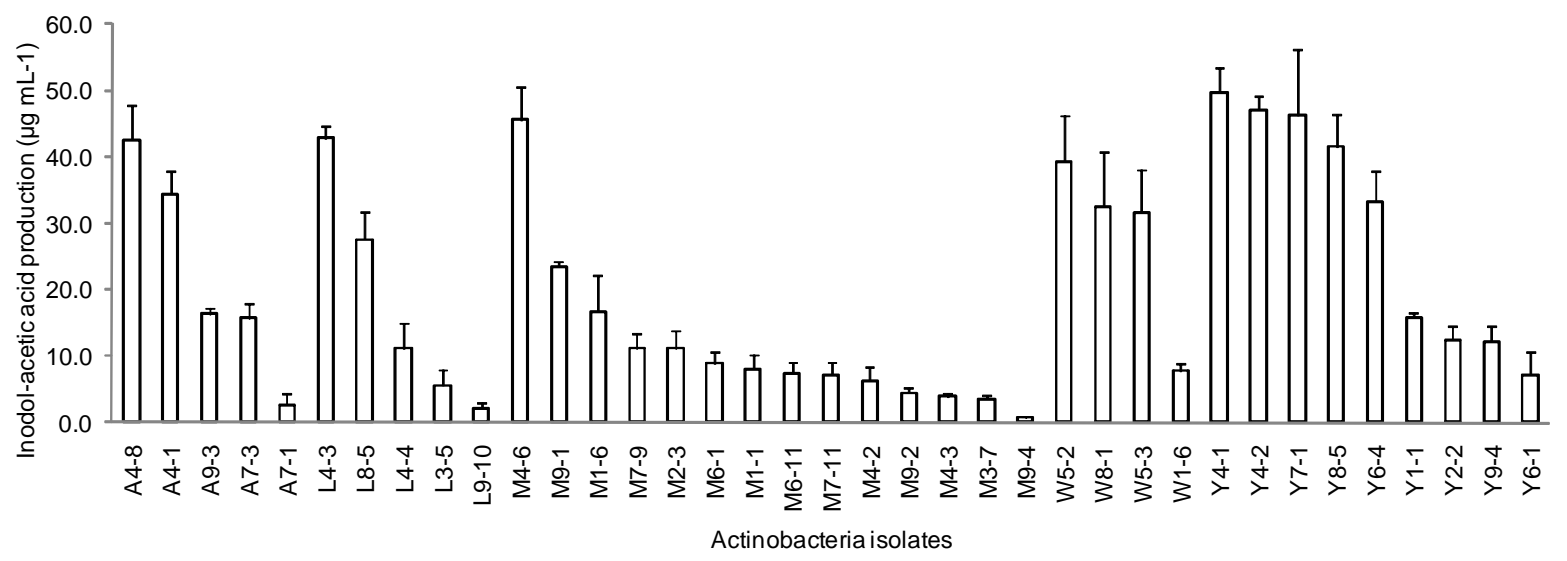

Figure 2 - Quantitative analysis of indole-acetic acid produced by actinobacteria isolated on culture media (AI, LNMS, MSSC, WYE and YCED). The first letter of the strain identification represents the culture medium used for isolation. Bars represent the standard errors of the means (3 replicates). 
in Brazil. In fact, the culture media used had implications not only in the isolation of actinobacteria but also to emphasize the great biotechnological potential of these microorganisms.

\section{References}

Akbari, G.A.; Ara, S.M.; Alikhani, H.A; Allahdad, I.; Arzanesh, M.H. 2007. Isolation and selection of indigenous Azospirillum spp. and the IAA of superior strains effects on wheat roots. World Journal of Agricultural Sciences 3: 523-529.

Anzai, K.; Nakashima, T.; Kuwahara, N.; Suzuki, R.; Ohfuku, Y.; Takeshita, S.; Ando, K. 2008. Actinomycete bacteria isolated from the sediments at Coastal and Offshore Area of Nagasaki Prefecture, Japan: diversity and biological activity. Journal of Bioscience and Bioengineering 106: 215-217.

Araújo, J.M.; Silva, A.C.; Azevedo, J.L. 2000. Isolation of endophytic actinomycetes from roots and leaves of maize (Zea mays L.). Brazilian Archives of Biology and Technology. Avaliable at: sci pdf\&pid $=$ S1516-89132000000400016\&lng $=$ en\&nrm $=$ iso\&tlng $=$ en. [Accessed Jun. 30, 2009]

Bric, J.M..; Bostock, R.M.; Silverstone, S.E. 1991. Rapid In Situ Assay for Indoleacetic Acid Production by Bacteria Immobilized on a Nitrocellulose Membrane. Applied and Environmental Microbiology, Washington 57: 535-538.

Carvalho, P.E.R. 1994. Brazilian Forest Species: Cultural Recommendations, Potentialities and Wood Usage. EMBRAPA-SPI, Brasília, DF, Brazil. 640p.

Crawford, D.L. 1978. Lignocellulose decomposition by selected streptomyces strains. Applied Environmental Microbiology 35: 1041-1045.

Crawford, D.L.; Lynch. J.M.; Whipps. J.M.; Ousley. M.A. 1993. Isolation and characterization of actinomycete antagonists of a fungal root pathogen. Applied and Environmental Microbiology 59: 3899-3905.

El-Tarabily, K.A.; Soliman, M.H.; Nassar, A.H.; Al-Hassani, H.A.; Sivasithamparam, K.; Mckenna, F.; Hardy, G.E.ST.J. 2000. Biological control of Sclerotinia minor using a chitinolytic bacterium and actinomycetes. Plant Pathology 49: 573- 583.

Gomes, N.C.M.; Heuer, H.; Schönfeld, J.; Costa, R.; MendonçaHagler, L.; Smalla, K. 2001. Bacterial diversity of the rhizosphere of maize (Zea mays) grown in tropical soil studied by temperature gradient gel electrophoresis. Plant and Soil 232: 167-180.

Gomes, R.C.; Semedo, L.T.A.S.; Soares, R.M.A.; Alviano, C.S.; Linhares, L.F.; Coelho, R.R.R. 2000. Chitinolytic activity of actinomycetes from a cerrado soil and their potential in biocontrol. Letters in Applied Microbiology 30: 146-150.

Goodfellow, M.; Williams, S.T. 1983. Ecology of Actinomycetes. Annual Review of Microbiology 37: 189-216.
Guerra, M.P.; Silveira, V.; Reis, M.S.; Schneider, L. 2002. Exploitation, management and conservation of Brazilian Pine (Araucaria angustifolia). p. 85-101 In: Simões, L.L.; Lino, C.F., eds. Sustainable Mata Atlântica. SENAC, São Paulo, SP, Brazil.

Hamdali, H.; Bouizgarne. B.; Hafidi. M.; Lebrihi. A.; Virolle. M.J.; Ouhdouch Y. 2008. Screening for rock phosphate solubilizing Actinomycetes from Moroccan phosphate mines. Applied Soil Ecology 38: 12-19.

Hsu, S.C.; Lockwood, J.L. 1975. Powdered chitin agar as a selective medium for enumeration of actinomycetes in water and soil. Applied and Environmental Microbiology 29: 422-426.

Hynes, R.K.; Leung, G.C.Y.; Hirkala, D.L.M.; Nelson, L.M. 2008. Isolation, selection, and characterization of beneficial rhizobacteria from pea, lentil, and chickpea grown in western Canada. Canadian Journal of Microbiology 54: 248-258.

Katznelson, H; Bose, B. 1959. Metabolic activity and phosphatedissolving capability of bacterial isolates from wheat roots, rhizosphere and non-rhizosphere soil. Canadian Journal of Microbiology 5: 79-85.

Lima, A.R.; Capobianco, J.P.R. 1997. Atlantic Forest: Institutional and Legal Advances for its Conservation. Instituto Socioambiental, Brasília, DF, Brazil. 111 p.

Merzaeva, O.V.; Shirokikh. I.G. 2006. Colonization of plant rhizosphere by actinomycetes of different genera. Microbiology 75: $226-230$

Miyadoh, S. 1993. Research on antibiotic screening in Japan over the last decade: a producing microorganisms approach. Actinomycetologica 7: 100-106.

Pereira, J.C.; Neves, M.C.P.; Drozdowicz, A. 1996. Quantification of the Whole Bacteria Population, Antibiotic Resistant Bacteria and Soil Actinomycetes. EMBRAPA-CNPAB. Seropédica, RJ, Brazil. 21 p.

Pridham, T.G.; Anderson, P.; Foley, C.; Lindenfelser, L.A.; Hesseltine, C.W.; Benedict, R.G. 1957. A selection of media for maintenance and taxonomic study of Streptomyces. Antibiotics Annual 1956/1957: 947-953.

Sousa, C.S.; Soares. A.C.F.; Garrido. M.S. 2008. Characterization of streptomycetes with potencial to promote plant growth and biocontrol. Scientia Agricola 65: 50-55.

Stackebrandt, E.; Raineyf. A.; Ward-Rainey. N.L. 1997. Proposal for a new hierarchic classification system. Actinobacteria classis nov. International Journal of Systematic Bacteriology 47: 479491.

Toledo, A.C.D.; Cardoso, E.J.B.N. 1975. Natural microflora effect and the soil supplementation on the biological control of rice Bakanae. Summa Phytopathologica 1: 81-86.

Received July 02, 2009

Accepted June 01, 2010 